\begin{tabular}{|l|l|l||}
\hline \multicolumn{2}{|c|}{ PublisherInfo } \\
\hline \hline PublisherName & $:$ & BioMed Central \\
\hline \hline PublisherLocation & $:$ & London \\
\hline \hline PublisherImprintName & $:$ & BioMed Central \\
\hline \hline
\end{tabular}

\title{
Cyclin D 1 in breast cancer is not associated with Ki67 but with ER
}

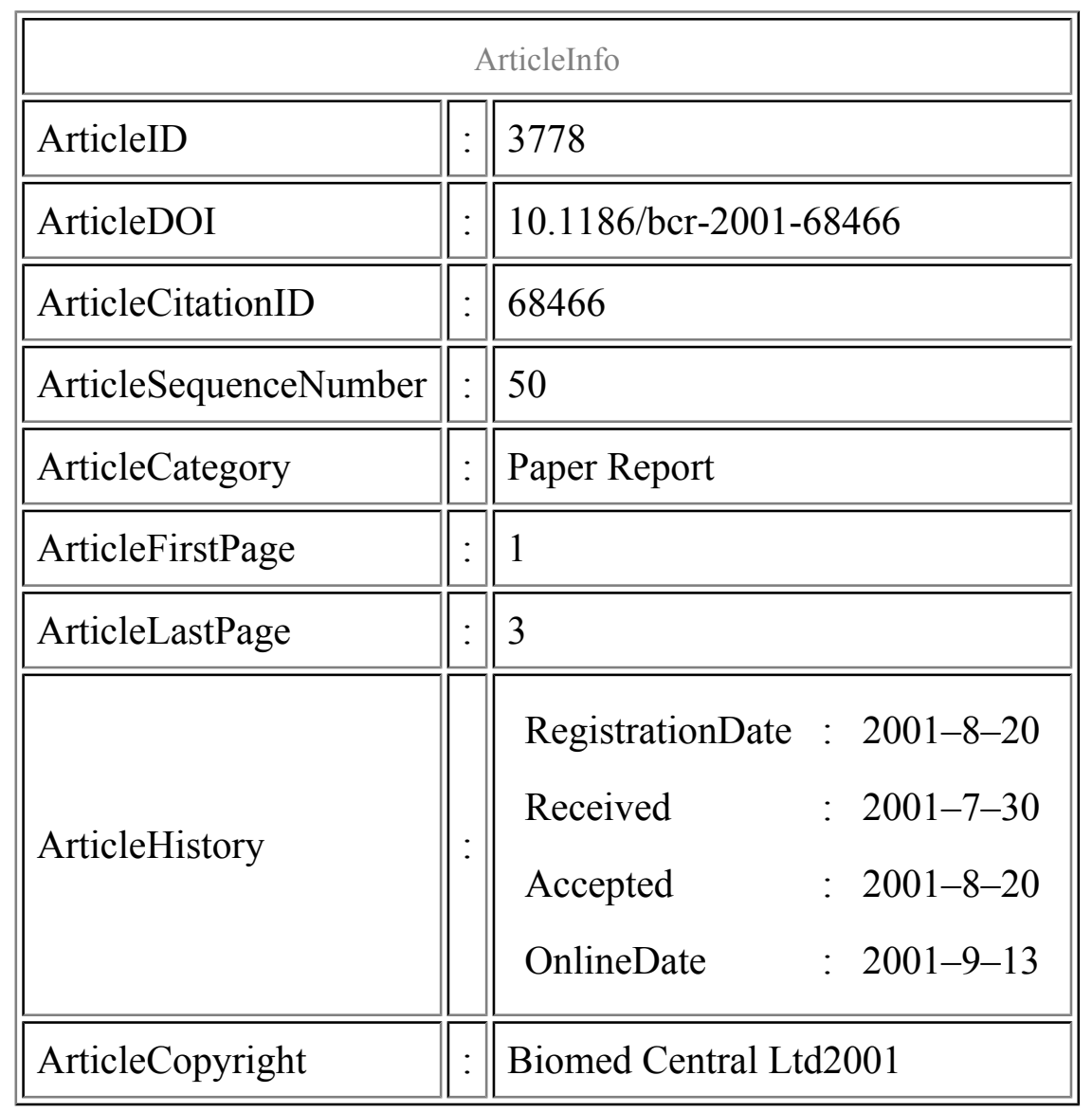




\begin{tabular}{|l|l|l||}
\hline ArticleGrants & $:$ & \\
\hline \hline ArticleContext & $:$ & 1305833 \\
\hline
\end{tabular}

George Skliris, ${ }^{\text {Aff1 }}$

Aff1 University of Leeds, UK

\section{Keywords}

Cancer, cyclin D1, immunohistochemistry, Ki67, normal breast, oestrogen receptor

\section{Context}

D-type cyclins are implicated in cell cycle regulation. The cyclin $\mathrm{D}_{1}$ gene is amplified in $15-20 \%$ of breast cancers while the protein is overexpressed in $50 \%$ of these cancers (see Additional information [1]). Overexpression of cyclin $\mathrm{D}_{1}$ has been linked with oestrogen receptor (ER)a, because it can stimulate transcriptional functions in the absence of oestrogen (see Additional information [2]). A negative association in normal breast has been reported for ERa and Ki67 (a proliferation marker), although this relationship changes in many precancerous and ER-positive cancers. Therefore, the aim of the study was to investigate the interaction between cyclin $\mathrm{D}_{1}$, ER and Ki67 in normal and malignant breast material.

\section{Significant findings}

The mean percentage of ER-positive cells in normal breast tissues was 20\%. Approximately $50 \%$ of the cyclin-D1-positive cells coexpressed ER. However, cyclin-D $D_{1}$-positive cells were detected in $70 \%$ of ER-positive invasive ductal carcinomas (IDCs) and in 30\% of ER-negative IDCs. In normal breast tissues, Ki67-positive cells accounted for 3\% of the epithelial cells while only $0.3 \%$ contained cyclin $\mathrm{D}_{1}$. In benign breast lesions no clear outcome was detected for cyclin $\mathrm{D}_{1}$ and Ki67. Invasive cancers showed a higher percentage of Ki67-positive cells than normal tissue and this was significantly higher in ERnegative than in ER-positive carcinomas. Overall a positive correlation between cyclin $\mathrm{D}_{1}$ and ERpositive cells was detected in normal and cancerous breast tissues, while a negative association was detected between cyclin $\mathrm{D}_{1}$ and Ki67. 


\section{Comments}

Cyclin $\mathrm{D}_{1}$ overexpression has been associated with low grade ER-positive breast cancers (see Additional information [3]). In this study no cyclin $\mathrm{D}_{1}$ positivity was detected in ER-negative breast cancers that contained a high percentage of Ki67-positive cells. A number of studies indicate that cyclin $\mathrm{D}_{1}$ overexpression increases progressively from normal breast epithelium to atypical ductal hyperplasia (ADH), to ductal carcinoma in situ (DCIS) and to invasive cancers respectively (see Additional information $[4,5]$ ). The authors observed that cyclin $\mathrm{D}_{1}$ was higher within in situ proliferations than in normal breasts, while in ADH cases similar values to those measured in ER-positive DCIS were seen. Therefore, they concluded that cyclin $\mathrm{D}_{1}$ was not the ideal marker for separating benign from malignant breast lesions. Future studies should investigate further the interactions of cyclin $\mathrm{D}_{1}$ and Ki67 expression in larger cohorts and include other histological carcinoma types.

\section{Methods}

Dual immunofluorescence immunohistochemistry

\section{Additional information}

1. Barnes DM: Cyclin D1 in mammary carcinoma. J Pathol 1998, 181:267-269 (PubMed abstract).

2. Zwijsen RML, Wientjens E, Klompmaker R, van der Sman J, Bernards R, Michalides RJAM: CDK-independent activation of oestrogen receptor by cyclin D1. Cell 1997, 88:405-415 (PubMed abstract).

3. van Diest PJ, Michalides RJ, Jannink L, van der Valk P, Peterse HL, de Jong JS, Meijer CJ, Baak JP: Cyclin D1 expression in invasive breast cancer. Correlations and prognostic value. $A m J$ Pathol 1997, 150:705-711 (PubMed abstract).

4. Alle KM, Henshall SM, Field AS, Sutherland RL: Cyclin D1 protein is overexpressed in hyperplasia and intraductal carcinoma of the breast. Clin Cancer Res 1998, 4:847-854 (PubMed abstract). 
5. Zhu XL, Hartwick W, Rohan T, Kandel R: Cyclin D1 gene amplification and protein expression in benign breast disease and breast carcinoma. Mod Pathol 1998, 11:1082-1088 (PubMed abstract).

\section{References}

1. Shoker BS, Jarvis C, Davies MPA, Iqbal M, Sibson DR, Sloane JP: Immunodetectable cyclin $\mathrm{D}_{1}$ is associated with oestrogen receptor but not $\mathrm{Ki} 67$ in normal, cancer and precancerous breast lesions. $\mathrm{Br} \mathrm{J}$ Cancer . 2001, 84: 1064-1068. 